Respiratory movements and rapid eye movement sleep in the foetal lamb. J. Physiol., 220: 119 (1972).

19. Finster, M., Mark, L. C., Morishima, H. O., Moya, F., Perel, J. M., James, L. S., and Dayton, P. G.: Plasma thiopental concentrations in the newborn following delivery under thiopental-nitrous oxide anesthesia. Amer. J. Obstet. Gynecol., 95: 621 (1966).

20. Jappelli, G.: La sincronizzazione dei movimenti respiratori con eccitamenti ritmici di nervi centripeti. Arch Fisiol., 3: 215 (1906).

21. Kattwinkel, J., Nearman, B. S., Fanaroff, A. A., Katona, P. G., and Klaus, M. H.: Apnea of prematurity. J. Pediat., 86: 588 (1975).

22. Khayutin, V. M.: Specific and non-specific responses of the vasomotor centre to impulses of spinal afferent fibres. Acta Physiol. Acad. Sci. (Hungary), 29: 131 (1966)

23. Merlet, C., Hoerter, J., Devilleneuve, C., and Tchobroutsky, C.: Mise en evidence de mouvements respiratoires chez la foetus d'agneau in utero au cours du dernier mois de la gestation. C. R. Acad. Sci. (Paris), 270: 2462 (1970).

24. Molina, A. F., Achard, O., and Wyss, O. A. M.: Respiratory and vasomotor responses to stimulation of afferent fibres in somatic nerves. Helv. Physiol. Pharmacol. Acta, 11: 1 (1953)

25. Scarpelli, E. M.: Perinatal respiration. In: E. M. Scarpelli and P. A. M. Auld: Pulmonary Physiology of the Fetus, Newborn and Child. (Lea \& Febiger, Philadelphia, 1975).
26. Scarpelli, E. M., Condorelli, S., and Cosmi, E. V.: Lamb fetal pulmonary fluid. I Validation and significance of method for determination of volume and volume change. Pediat. Res., 9: 190 (1975)

27. Scarpelli, E. M., Real, F. J. P.. and Rudolph. A. M.: Tracheal motion during eupnea, J. Appl Physiol., 20: 473 (1965)

28. Widdicombe, J. G.: Respiratory reflexes. In: W. O. Fenn and H. Rahn Handbook of Physiology, Section 3: Respiration, Volume I, p. 585 (American Physiological Society, Washington, D. C.. 1964).

29. Younes, M., Arkinstall, W., and Milic-Emili, J.: Mechanism of rapid ventilatory compensation to added elastic loads in cats. J. Appl. Physiol.. 35: 443 (1973).

30. Air Shield, Hatboro, Pa.

31. Grass Instruments, Quincy, Mass.

32. Dr. Scarpelli is a recipient of a Career Development Award from the National Heart and Lung Institute of the National Institutes of Health.

33. This research was supported by grants from the National Heart and Lung Institute, National Institutes of Health (HL 16137); New York Heart Association grant-in-aid; and Health Research Council of the City of New York (U-2091E).

34. Requests for reprints should be addressed to: E. M. Scarpelli, M. D., Ph.D. Department of Pediatrics, Albert Einstein College of Medicine, 1300 Morris Park Ave., Bronx, N. Y. 10461 (USA).

35. Accepted for publication July 14, 1975.

\title{
Serum Glutathione Reductase and Cystic Fibrosis
}

\author{
BURTON L. SHAPIRO, ${ }^{(18)}$ Q. T. SMITH, AND W. J. WARICK \\ Department of Oral Biology, School of Dentistry and Department of Pediatrics, University of Minnesota Health Sciences Center, \\ Minneapolis, Minnesota, USA
}

\section{Extract}

Serum glutathione reductase (NADPH:GSSG oxidoreductase, EC. 1.6.4.2 (GR)) has been examined in cystic fibrosis subjects (CF), obligate CF heterozygotes, and control subjects. Serum protein concentration was similar in the three groups. Regardless of the units used to express activity (milligrams of protein or milliliters of serum) or whether or not samples were dialyzed against water or phosphate buffer, mean serum $G R$ in $C F$ was greater than in control subjects $(P<\mathbf{0 . 0 0 2})$ in all series over several years. Under the above assay conditions no difference in serum GR between control subjects and carriers was detected. Calculated and assayed values of combined control and CF sera agreed as did expected and observed $50 \%$ activity in 1:2 sera dilutions in CF, control subjects, and carriers. Addition of FAD to incubation media did not effect enzyme activity in the three groups. Differences between CF and control subjects persisted after dialysis in membranes permitting passage of molecules of approximately $12,000 \mathrm{~mol}$ wt or less. These findings would tend to exclude the effect of extraneous serum factors in explaining the differences between $\mathrm{CF}$ and control subjects. The percentage of initial GR activity after four days storage $\left(0-4^{\circ}\right)$ was significantly greater in $\mathrm{CF}$ than in control subjects $(P<\mathbf{0 . 0 2 5})$. The effect of heparin on serum GR was recorded as the percentage of activity after incubation with heparin vs. activity in the standard assay for individual subjects. The effect of incubation with $5 \mu \mathrm{g} / \mathrm{ml}$ sparin on serum GR activity was greater in control subjects than in carriers $(P<0.0005)$ and $\mathbf{C F}(P<\mathbf{0 . 0 0 0 5})$. Mean serum $\mathbf{G R}$ activity in $\mathrm{CF}$ and carriers was unaffected by heparin, whereas mean activity in control subjects was decreased. In no control was the percentage of initial activity with heparin greater than the mean of $\mathrm{CF}$ and carrier groups. Only 3 of $20 \mathrm{CF}$ and 4 of 20 carrier individuals had percentages lower than the control mean. The $C F$ and carrier distributions were clearly different from the control distribution. Serum GR was determined in seven non-CF individuals with chronic obstructive pulmonary disease (COPD). Activity in the COPD was different from $C F$ and no different from control subjects. In none of these controls or COPD was serum GR as great as the CF mean. Serum GR in no CF was as low as the mean of control subjects or COPD. It is concluded that serum GR activity is greater in CF than in control subjects, carriers, and non-CF COPD subjects; that the difference in activity is not attributable to an extraneous serum factor, that the activity difference is not secondary to chronic respiratory disease; that in comparison with control subjects, GR from CF serum behaves differently after storage; and that serum GR from CF and carriers behaves differently from control GR in the presence of heparin.

\section{Speculation}

Abnormal activity of glutathione reductase may be fundamentally related to the pathogenesis of cystic fibrosis.

Despite numerous studies (7), the abnormal gene product in cystic fibrosis (CF) and hence its molecular basis is not yet known. The generally held view of CF pathogenesis concerns an abnormal transport of ions and other small molecules in exocrine tissues (8). Because enzyme systems of the pentose phosphate pathway are localized at sites of ion transport in salivary glands and other tissues $(11,12)$, we examined this system in CF. In red blood cells (RBC's) mean glucose-6-phosphate dehydrogenase (D-glucose6-phosphate:NADP oxidoreductase, EC. 1.1.1.49) activity was increased and the mean ratio of NADPH to $\mathrm{NADP}^{+}$was decreased in $\mathrm{CF}$ in comparison with age- and sex-matched controls 
(13). GR of RBC's may be considered part of the pentose phosphate pathway because of its relative specificity for NADPH (2). Therefore the GR system was examined. RBC GR activity and total glutathione (GSSG + GSH) were increased in CF in comparison with controls (15). No abnormalities of RBC indices or constants in CF subjects were found (15) that would account for these data. Since characteristic biologic properties of body fluids in carriers for the condition and in $\mathrm{CF}$ patients have been reported (7), we decided to assay serum GR activity in CF patients, age- and sex-matched control subjects, and obligate heterozygotes for CF. In the course of these studies we have noted consistent differences in serum GR between CF and control subjects. We now report findings concerning serum GR activity, serum protein concentration; serum GR activity after storage, exposure to heparin and to FAD; effects of dialysis, of combining CF and control serum, and of dilutions on GR activity in CF subjects, carriers and control subjects. Serum GR has been determined also in a group of non-CF patients with COPD.

\section{METHODS}

Diagnosis of CF was based on elevated sweat chloride tests and clinical findings. All CF patients were ambulatory. Obligate heterozygotes were parents of CF children. Ten to $30 \mathrm{cc}$ venous blood were obtained from each subject. Sera were collected after 1 $\mathrm{hr}$ and stored at $0-4^{\circ}$

Serum GR activity was determined at $25^{\circ}$ on duplicate $0.2-\mathrm{ml}$ aliquots of serum (except when the effect of dilution was examined) from the decrease in optical density at $340 \mathrm{~nm}$ resulting from oxidation of NADPH to NADP ${ }^{+}$by GR in the presence of GSSG (5). One unit GR activity is defined as that amount of enzyme which reduces $1 \mu \mathrm{mol}$ GSSG in $1 \mathrm{hr}$ at assay temperature. In more recent studies, enzyme activity was determined at $37^{\circ}$ with preincubation of all reagents at this temperature. Serum enzyme activity was recorded usually as units per $\mathrm{ml}$ serum. In an additional series enzyme activity was expressed as GR units per mg serum protein using the Lowry procedure (9).

Aliquots of serum from an additional nine $\mathrm{CF}$, nine carriers, and nine control subjects were assayed for GR: (l) after dialysis overnight against $0.067 \mathrm{M}$ phosphate buffer, $\mathrm{pH} 6.6,4^{\circ}$, (2) after dialysis overnight against distilled-deionized water at $4^{\circ}$, and (3) without dialysis. Each dialysis bag containing $2 \mathrm{cc}$ serum was placed in 5-6 liters of buffer or water. According to the supplier the dialysis tubing used retains molecules of molecular weight greater than 12,000 (16).

Samples were routinely stored overnight in a refrigerator before assay. As a test of storage stability assays were performed also 4 days after collection having been stored at $0-4^{\circ}$ and activity compared with initial activity for each individual sample.

It has been reported that heparin inhibits serum GR activity (6). Therefore, three sets of pooled serum samples of CF, carriers, and control subjects were assayed at $37^{\circ}$ in duplicate for GR after 5 min of preincubation with all reagents except GSSG in the presence of $0,1,5,10,25$, and $100 \mu \mathrm{g} / \mathrm{ml}$ heparin. Each pooled sample consisted of five individuals. Results from the analyses of these samples indicated that the greatest difference between carrier and control serum GR activity occurred in the presence of $5 \mu \mathrm{g} / \mathrm{ml}$ heparin. Therefore, serum from $20 \mathrm{CF}, 18$ control, and 20 carrier individuals was assayed with $5 \mu \mathrm{g} / \mathrm{ml}$ heparin and without heparin under the above assay conditions.

GR activity was determined in whole sera and in sera diluted 1:2 with buffer used in the assay reaction. Portions of sera from 15 pairs of $\mathrm{CF}$ and control samples were combined in 1:1 ratios. Each sample was assayed individually. Calculated and assayed averages were compared. Assay mixtures containing all components for serum GR determination except GSSG but in addition 0,1 , or 10 $\mu \mathrm{g} \mathrm{FAD}$, were incubated at $37^{\circ}$ for $15 \mathrm{~min}$. GR activity was then determined by the usual procedure after addition of GSSG. The effect of FAD was tested in five controls, six CF, and six carriers.

Finally, GR was determined in serum obtained from seven individuals suffering from COPD: agammaglobulinemia with
COPD $(n=2)$, hypogammaglobulinemia with COPD $(n=1)$, COPD $(n=2)$, chronic upper respiratory infection and cough $(n=$ $1)$, and asthma $(n=1)$ and compared with $12 \mathrm{CF}$ and 12 control subjects. Serum from these subjects was dialyzed overnight against distilled-deionized water as described above.

\section{RESULTS}

In all series over several years, serum GR activity was greater in CF subjects in comparison with age- and sex-matched control subjects. No difference between control subjects and carriers was noted (Table 1). In order to determine whether differences were due to increased concentration of serum proteins in CF we assayed milligrams of protein per $\mathrm{ml}$ serum in a sample of subjects. No differences among CF, carriers, or control subjects for serum protein concentration were detected: [milligrams protein per $\mathrm{ml}$ serum CF $=80.4 \pm 1.9(n=14)$, control subjects $=77.1 \pm 2.3(n$ $=12)$, carriers $=79.1 \pm 2.5(n=13)]$. Serum GR was assayed in a portion of the individuals in whom serum protein determinations were made and calculated in units of GR per $\mathrm{ml}$ protein. Using these units GR activity was again greater in CF in comparison with control subjects $(P<0.02)$. Carriers were not different from control subjects. In the additional series of nine CF, nine carriers, and nine control subjects, the mean serum GR in the CF sample was greater than in control subjects regardless of units used in both dialyzed and nondialyzed aliquots $(P \leq 0.002)$ (Fig. 1).

Serum dilutions of $1: 2$ in comparison with undiluted samples resulted in the following enzyme activity: heterozygotes $(n=8)$ : $49.8 \pm 0.7 \%, \mathrm{CF}(n=4): 48.2 \pm 1.3 \%$, and control subjects $(n=$ 4): $50.3 \pm 0.8 \%$. Assayed values of serum GR in $151: 1$ mixtures of serum from $\mathrm{CF}$ and control subjects were no different from the

Table 1. Serum glutathione reductase activit!

\begin{tabular}{ccccc}
\hline Series & Group & $n$ & Mean $^{1} \pm$ SEM & $P^{2}$ \\
\hline $\begin{array}{c}1972 \text { assayed } \\
\text { at } 25^{\circ}\end{array}$ & $\begin{array}{c}\text { Cystic } \\
\text { fibrosis } \\
\text { Control }\end{array}$ & 10 & $2.025 \pm 0.09$ & \\
& 10 & $1.545 \pm 0.10$ & $<0.005$ \\
1973 assayed & Cystic & 11 & $2.311 \pm 0.09$ & \\
at $37^{\circ}$ & fibrosis & 13 & $2.004 \pm 0.06$ & $>0.005$ \\
& $\begin{array}{c}\text { Control } \\
\text { Carrier }\end{array}$ & 13 & $1.972 \pm 0.05$ & $>0.25$ \\
& & & &
\end{tabular}

${ }^{1}$ Units glutathione reductase per $\mathrm{ml}$ serum at indicated temperature.

${ }^{2}$ Student's $t$ test.

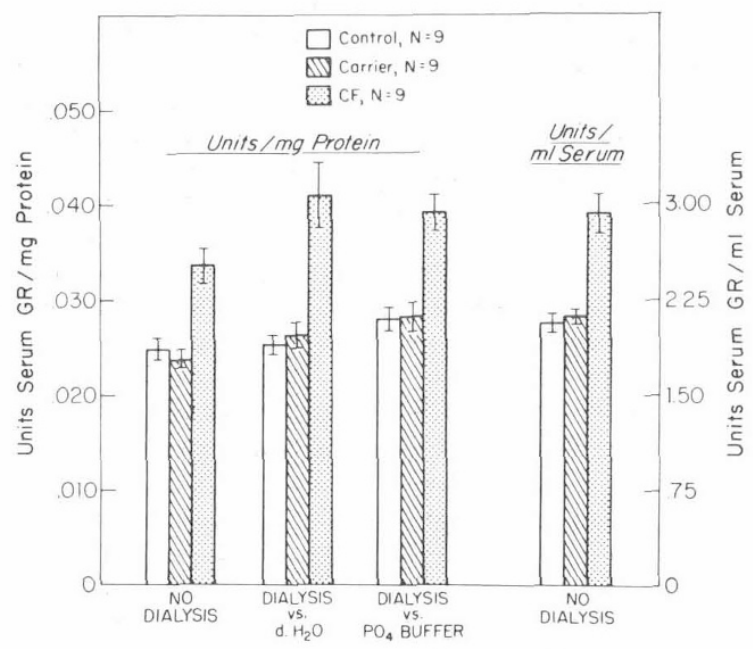

Fig. 1. Serum glutathione reductase $(G R)$ activity (at $37^{\circ}$ ) assayed under various conditions in the same individuals. Each bar records mean activity under the conditions specified. The brackets show \pm I SEM. $C F$ : cystic fibrosis. 
calculated average of the pairs: percentage (calculated average to assayed value) $=103.2 \pm 2.7 \%$.

The mean value of GR activity after 4 days of storage in comparison with initial activity was significantly greater in CF than in control subjects (Table 2). Mean values from both control and carrier samples retained initial activity. Mean activity in CF was increased after storage.

The pattern of effect of various concentrations of heparin was different in pooled serum samples from CF, carriers, and control subjects (Fig. 2). Since separation of CF and carriers from control subjects appeared to be greatest at heparin concentrations of 5 $\mu \mathrm{g} / \mathrm{ml}$ we tested the effect of preincubation of serum from individuals with this concentration. The study was repeated on two groups with more than a year intervening between them. Findings in both series were similar and are combined in Table 2. Differences in percentage of activity with heparin in comparison with no heparin between CF and carriers on the one hand and control subjects on the other were statistically highly significant. Overlap among individuals in the three groups occurred, but as can be seen in Figure 3, in no control individual was percentage of initial activity with heparin greater than the mean of the CF and carrier groups. Only 3 of $20 \mathrm{CF}$ and 4 of 20 carriers had percentages lower than the control mean. The CF and carrier distributions are clearly different from the control distribution. The addition of FAD to incubation media did not affect GR activity in any of the groups. The percentage of GR activity in the presence of FAD in comparison with no FAD was $(1$ and $10 \mu \mathrm{g} / \mathrm{ml}$ FAD, respectively): $95.7 \pm 3.9(\mathrm{CF}), 98.0 \pm 2.8$ (carrier), $101.2 \pm$ 4.6 (control); and 102.5 $\pm 3.1(\mathrm{CF}), 102.0 \pm 4.2$ (carrier), and $105.6 \pm 2.2$ (control)

Assayed values from 7 individuals suffering from COPD together with values from an additional $12 \mathrm{CF}$ subjects and 12 control subjects are plotted in Figure 4. Clearly, serum GR activity in the COPD patients was different from that in CF and was similar to serum GR activity in control subjects. In none of the control subjects or non-CF COPD subjects was serum GR as great as the CF mean. Serum GR in no CF subject was as low as the mean of control subjects or non-CF COPD subjects.

\section{DISCUSSION}

Data accumulated over several years and under a variety of conditions have demonstrated repeatedly that mean serum GR in $\mathrm{CF}$ is elevated in comparison with obligate heterozygotes and control subjects. The altered activity of an enzyme does not, of course, distinguish between the possibilities that there is a quantitative difference in the amount of enzyme present or that the

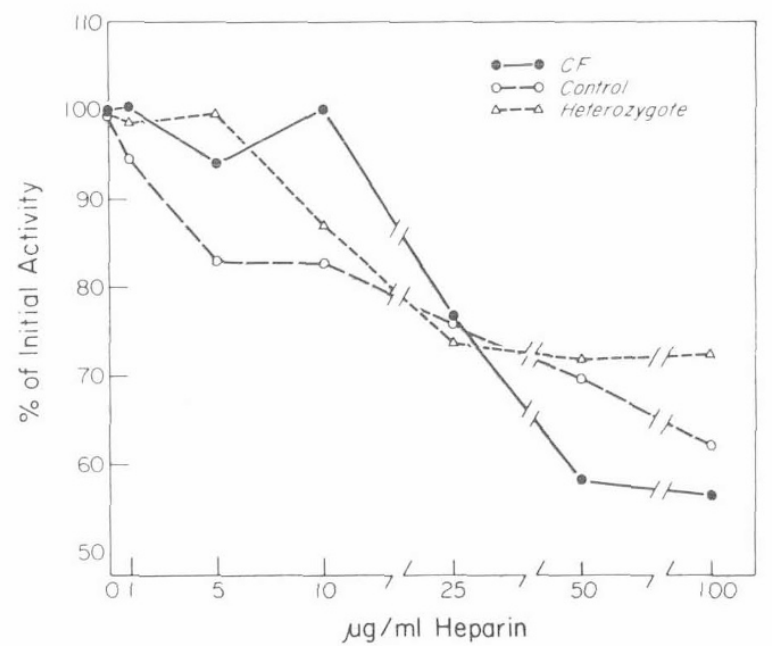

Fig. 2. Effect of varying concentrations of heparin on serum glutathione reductase from pooled samples. Each symbol represents the mean of duplicate runs of three sets of pooled samples. Each pooled sample contained five individuals. $C F$ : cystic fibrosis.
Table 2. Effects of storage and heparin on serum glutathione reductase activity

\begin{tabular}{|c|c|c|c|c|}
\hline Treatment & Group & $n$ & $\begin{array}{l}\% \frac{\text { treatment }}{\text { no treatment }} \\
(\text { mean } \pm \text { SEM })\end{array}$ & $P^{1}$ \\
\hline \multirow[t]{3}{*}{$\begin{array}{l}\text { Storage }\left(0-4^{\circ}\right) \\
\quad \text { for } 4 \text { days }\end{array}$} & $\begin{array}{l}\text { Cystic } \\
\text { fibrosis }\end{array}$ & 11 & $111.4 \pm 4.4$ & \multirow{3}{*}{$\begin{array}{l}<0.025 \\
>0.10\end{array}$} \\
\hline & Control & 13 & $98.3 \pm 3.2$ & \\
\hline & Carrier & 13 & $102.9 \pm 2.4$ & \\
\hline \multirow[t]{3}{*}{$\begin{array}{l}5 \mu \mathrm{g} / \mathrm{ml} \text { hep- } \\
\quad \text { arin }\end{array}$} & $\begin{array}{l}\text { Cystic } \\
\text { fibrosis }\end{array}$ & 20 & $102.5 \pm 3.2$ & $<0.0005$ \\
\hline & Control & 18 & $88.5 \pm 1.4$ & \multirow{2}{*}{$<0.0005$} \\
\hline & Carrier & 20 & $99.3 \pm 2.2$ & \\
\hline
\end{tabular}

${ }^{1}$ Student's $t$ test.

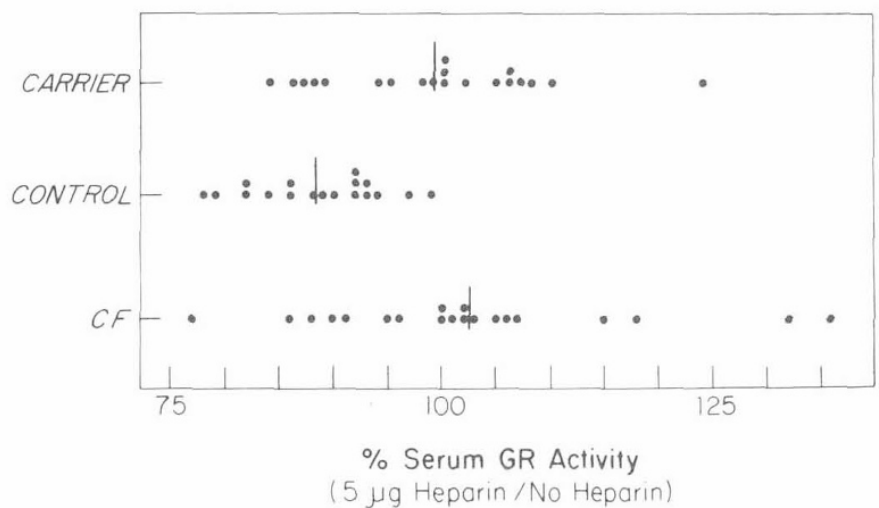

Fig. 3. The effect of heparin on serum glutathione reductase $(G R)$ Each dot represents an individual. Vertical lines depict means of percent activity after incubation with $5 \mu$ g heparin in comparison with no heparin in each group. $C F$ : cystic fibrosis.

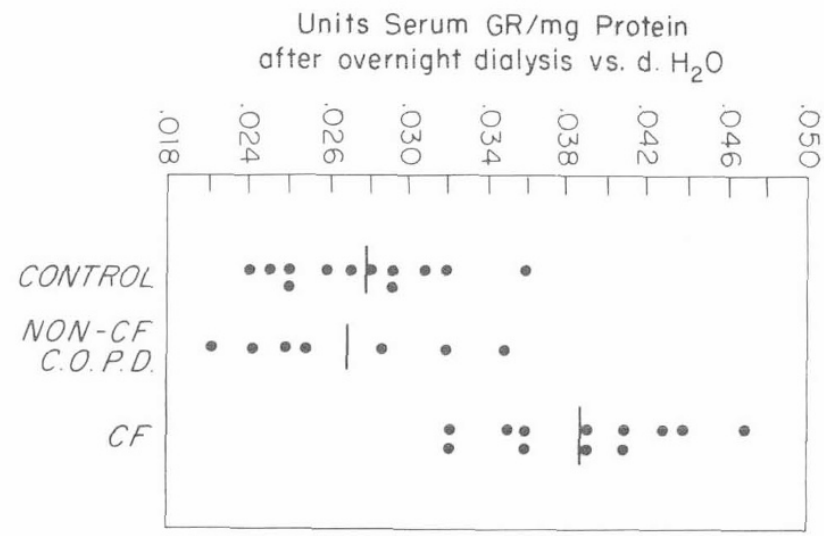

Fig. 4. Individual serum glutathione reductase $(G R)$ activity assayed at $37^{\circ}$ after dialysis against distilled water. Each dot represents the mean of triplicate assays on each individual. Asthma $(n=1)$, chronic obstructive pulmonary disease $(C O P D)(n=2)$, upper respiratory infection and chronic cough $(n=1)$, hypogammaglobulinemia and COPD $(n=1)$, and agammaglobulinemia and $\operatorname{COPD}(n=2)$. CF: cystic fibrosis.

enzyme protein is altered and expresses different activity under assay conditions. This distinction is an extremely difficult one to resolve. In addition to alterations in molecular structure, enzyme activity differences may reflect the rate of synthesis or degradation of the enzyme itself; or substrate, cofactor, or product differences: or extraneous factors such as inhibitors or activators (4). The most direct explanation for the increased serum GR in CF may be that the enzyme activity difference is secondary to the disease process and/or therapy. However, several observations suggest to us that 
such an explanation may be too facile and that in fact GR may be related directly to the basic defect in CF.

The possibility that a serum inhibitor or activator of small molecular size in sera in one or the other groups accounted for the activity differences between CF and control subjects was tested by assaying aliquots of samples dialyzed against both distilled-deionized water and phosphate buffer. The relative difference between $\mathrm{CF}$ and control subjects was maintained (Fig. 1). The agreement between calculated and assayed values of combined control and CF sera and agreement between 1:2 serum dilutions of $50 \%$ activity in control, carriers, and CF subjects similarly makes unlikely the presence of a critical level of some factor in any one of the groups that would account for the observed activity differences. Beutler (1) reported that hemolyzate GR is enhanced by the addition of FAD. However, no such effect was found here in the serum GR assays in the CF. carrier, or control samples. These data do not exclude the possibility of real increased levels of GR in serum of $\mathrm{CF}$ subjects. They appear to rule out the presence of some molecule that would lead to greater apparent activity in CF serum or decreased activity in control subjects at the time of assay. Moreover, serum GR activity in seven COPD patients was similar to control subjects. This finding would further tend to rule out factors secondary to obstructive respiratory disease as being responsible for the serum GR differences from normal observed in $\mathrm{CF}$.

Greater relative activity of serum GR in CF in comparison with controls after storage or exposure to heparin suggests that serum $\mathrm{GR}$ in $\mathrm{CF}$ behaves differently from that in control subjects. These differences do not seem to be due to quantitative differences between $\mathrm{CF}$ and control subjects since each subject was compared with himself to determine percentage of initial activity. Greater mean activity after storage of GR in serum of CF subjects coincides with similar results with lymphocyte GR (14). The relative difference between control subjects and CF subjects after storage in two systems as diverse as white blood cells (WBC's) and serum is remarkably similar. Furthermore, in comparison with control subjects, serum GR in carriers as well as in CF responded differently to heparin. The heparin studies were performed on nondialyzed samples. However, in other experiments we noted no consequence of dialysis on heparin effects on serum GR. Heparin has been reported to reverse ciliostatic activity of CF fluids (3) and to abolish a sodium transport effect after retrograde perfusion of salivary gland ducts by CF fluids (10). However, an explanation of the relationship between these phenomena and the differential effect of heparin on serum GR in CF and control subjects is premature.

Nothing is known about possible relationships between primary and secondary abnormalities in CF and GR. Therefore, it is premature to assess the relationship of these serum GR findings to CF. Little is known about the function of GR other than its probable role in the maintenance of cellular $-\mathrm{SH}$ groups. GR may be involved in the pathogenesis of CF through such a role and/or its role in $\mathrm{NADP}^{+}$production $(13,15)$. In any case, the observation of ( 1 ) repeated differences between CF and control subjects for serum GR activity in addition to (2) earlier findings of GR differences between CF and control subjects in RBC's and WBC's, (3) the different response of GR in $\mathrm{CF}$ and control subjects to storage in serum and WBC's (4) the different response of CF and carriers in comparison with control subjects to heparin and (5) the apparently normal serum GR in COPD is of interest. The differences noted were statistical; individuals cannot be categorized as CF, carriers, or control subjects in terms of activity or stability of serum GR. Even if the GR molecule in CF is of variant form, and this is far from proven, the absence of discrete differences in enzyme activity between groups is not unexpected. Clearly defined bimodal or trimodal distributions of enzyme activity because of inherited differences which exist in the popula- tion are the exception rather than the rule (4). In light of the usual continuity of enzyme activity among variants in a population, the inherent complexity of serum, the possible genetic heterogeneity of $\mathrm{CF}$, and the indirectness of enzyme activity as an indicator of genetic differences among individuals, the repeated and statistically highly significant GR differences observed appear striking. These facts suggest to us that GR is implicated in the pathogenesis of CF.

\section{SUMMARY}

The mean activity of serum GR has been shown to be greater in $\mathrm{CF}$ samples than in controls. No difference in enzyme activity between carriers and control subjects was detected. These observations were similar when recorded in terms of milliliters of serum or in milligrams of protein. Similar results were obtained after dialysis against water or phosphate buffer. Results from (I) combinations of sera from CF and control subjects, (2) dilution of serum from CF, control subjects, and carriers and (3) persistence of differences between $\mathrm{CF}$ and control subjects after dialysis lead us to conclude that the differences between CF and control subjects were not due to an extraneous serum substance. Serum GR differences between $\mathrm{CF}$ and control subjects after storage and differences between $\mathrm{CF}$ and carriers on the one hand and control subjects on the other after incubation of serum with heparin suggest that GR behaves differently in CF. Serum GR activity in seven individuals with chronic obstructive pulmonary disease did not differ from control subjects. These findings suggest to us that $\mathrm{GR}$ is involved in the pathogenesis of CF.

\section{REFERENCES AND NOTES}

1. Beutler, E.: Glutathione reductase: Stimulation in normal subjects by riboflavin stimulation. Science, 165: 613 (1969).

2. Brewer, G. J.: 6-Phosphogluconate dehydrogenase and glutathione reductase. In: J. J. Yunis: Biochemical Methods in Red Cell Genetics, p. 139 (Academic Press, New York, 1969).

3. Doggett, R. G., Harrison, G. M.. and Patrick, T. A.: Cystic fibrosis: In vivo reversal of ciliostatic character of serum and parotid secretions by heparin. Nature New Biol., 243: 250 (1973).

4. Harris, H.: The Principles of Human Biochemical Genetics, Ed. 2 (North-Holland Publishing Co., Ltd., London, 1975).

5. Horn, H.-D.: Glutathione reductase. In: H.-U. Bergmeyer: Methods of Enzymatic Analysis, p. 876 (Academic Press. New York, 1965).

6. Horn, H.-D., and Bruns, F. H.: DPNH- und TPNH-Gluthion-reduktase im Serum des Menschen. Biochem. Z., 331: 58 (1958).

7. Lancet (lead article): Developments in cystic fibrosis research. Lancet, ii: 307 (1973)

8. Lobeck, C. C.: Cystic fibrosis. In: J. B. Stanbury, J. B. Wyngaarden, and D. S. Fredrickson: The Metabolic Basis of Inherited Disease, Ed. 3 p. 1605 (McGraw-Hill Book Co., New York, 1972).

9. Lowry, O. H., Rosebrough, N. J., Farr, A. L., and Randall, R. J.: Protein measurement with the Folin phenol reagent. J. Biol. Chem.. 193: 265 (1951).

10. Mangos, J. A., and McSherry, N. R.: Studies on the mechanism of inhibition of sodium transport in cystic fibrosis of the pancreas. Pediat. Res., 2: 378 (1968).

11. Shapiro, B. L.: The pentose phosphate shunt and active ion transport in salivary glands. Program and Abstracts of the 47th General Meeting of the IADR, No. 503 (1969).

12. Shapiro, B. L.: Enzyme histochemistry of embryonic nasal mucosa. Anat. Rec.. 166: $87(1970)$

13. Shapiro, B. L., Lee, S. M., and Warwick, W. J.: The pentose phosphate pathway in cystic fibrosis erythrocytes. Biochem. Biophys. Res. Commun., 39: 816 (1970).

14. Shapiro, B. L., Smith, Q. T., and Martinez, A.: White-cell glutathione reductase in cystic fibrosis. Lancet, ii: 1020 (1974).

15. Shapiro, B. L., Smith, Q. T., and Warwick, W. J.: Red cell glutathione and glutathione reductase in cystic fibrosis. Proc. Soc. Exp. Biol. Med. 144: 181 (1973).

16. Catalog no. 8-667a, Fisher Scientific Co., Pittsburgh, Pa.

17. We acknowledge the cooperation and interest in these studies by Warren J. Warwick, M.D., Director of the Cystic Fibrosis Clinic University of Minnesota. We thank Ana B. Martinez for her continued and diligent contribution to these studies.

18. Requests for reprints should be addressed to: B. L. Shapiro, D.D.S., Ph.D. Department of Oral Biology, Health Sciences Unit A17-226, University of Minnesota School of Dentistry, Minneapolis, Minn. 55455 (USA).

19. Accepted for publication July 15, 1975. 